\title{
On the Codification of International Law ${ }^{1}$
}

On 13 March 1930, the first conference on the codification of international law will convene in The Hague. In the first Place, is this a feasible task and, if so, can it be performed in our times? If it is possible, then in what scope and using what method?

The word "codification", through the most immediate association, brings to mind the idea of a code, which is to say, a statute that systematically and exhaustively regulates some large segment of community life; it is used to refer to a uniform statute, relying on a single conception, subordinated to a single guiding idea and, finally, free from loopholes and internal contradictions. France boasts eight codes, the most illustrious being the Napoleonic Civil Code of 1804, which encompassed this huge domain of human relations in 2,281 articles; the Austrian Civil Code of 1811 managed to subsume this domain in as few as 1,502 articles. Only one hundred years later-we ignore here Italian, Spanish and Portuguese codes - one can mention other monuments of legislation which equal the previous ones in importance: the German Civil Code, in force since 1 January 1900, the Swiss Code that came into force as of 1 January 1912 and, finally, the last one, which will be counted among

1 Translated from: B Winiarski, O kodyfikacji prawa międzynarodowego, "Ruch Prawniczy, Ekonomiczny i Socjologiczny” 1930, 1, pp. 144-159 by Tomasz Żebrowski and proofread by Stephen Dersley and Ryszard Reisner. The translation and proofreading were financed by the Ministry of Science and Higher Education under 848/2/P-DUN/2018. 
the greatest: Codex iuris canonici of 1917, encompassing the entire legal life of the Church in 2,214 canons.

If those codification enterprises succeeded, it was first of all possible because the legal norms that were to be included in the codes had reached a high degree of perfection. For thousands of years, millions and millions of events, and human relations had been regulated by norms, which for this very reason were able to attain a high degree of generality. How many sale and purchase transactions were needed, and in what diverse conditions, involving a great variety of objects and transacting parties (e.g. from buying a wife, serfs, or an office, etc. to securities, an insurance policy or a lottery ticket), to be able to capture the entire institution of sale-purchase in a few sections of a civil statute! For thousands of years, they had been worked on by creative juristic minds. Customary law was written down, systematised, supplemented and amended by way of legislation until the norms became so certain and the institutions had crystallised to such an extent that codification was only a natural crowning of the work of centuries. It can be said that the Napoleonic Code had existed in all its details, before it was drafted. How then, did the Code of Canon Law arise? Pope Pius X commanded ut universae Ecclesiae leges, ad haec usque tempora editae, lucido ordine digestae, in unum colligerentur, amotis inde quae abrogatae essent aut obsoletae, aliis, ubi opus fuisset, ad nostrorum temporum conditionem propius aptatis.

The mainspring of all codification enterprises is almost always a powerful extra-legal factor: aspirations for greater political unity. The Napoleonic Code is an affirmation of a new France, which emerges from the revolutionary turmoil as not only "one and indivisible", but also strongly centralised. The Austrian Code was meant to reinforce the Habsburg monarchy, which was held together as a patchwork. The German Civil Code, in turn, capped the unification of Germany. It is for this very reason that the Congress Kingdom of Poland instinctively defended its civil code as a sign of its separate identity vis-à-vis Russia, and the Poles now yearn for a Polish civil code for the same rea- 
son, since it will not only crown the process of national unification, but also serve as a powerful unifying factor and the surest safeguard of unity for the future.

International law, the body of legal norms regulating relations between states, is an entirely different matter. The number of states who are its subjects is very limited indeed; it now stands at only about three score. Relations between them, despite the huge development of international communications, economic and cultural exchange, and despite their ever-closer interdependence on each other, are far less intensive than between individuals. Moreover, not all these relations are governed by international law: vast domains are found outside its limits. They belong to internal matters and as such are exclusively subject to domestic jurisdiction. The number of facts regulated by international law is relatively small; these are events and relations of a very diverse character and not recurrent. The abstracting mind of a jurist has not extracted enough elements from them yet that would allow him to reduce the body of international law norms to a number of institutions arranged in a logical system.

These norms are distinguished by a low degree of generality, they are very specific and detailed, and bear clear signs of the circumstances to which they have been adapted; the international law systematics in question is still in its infancy.

It is to custom that we owe the most ancient and consolidated and the most broadly adopted norms of international law. If they share all the advantages of customary law, however, they share its disadvantages as well, such as uncertainty if a rule has already become a binding norm and to what extent, or if it already has perchance ceased to be one, not to mention the inconsistency of norm construction and application. These disadvantages are aggravated by the fact that in international relations there is no authority that would resolve doubts and establish norms. Almost everything depends on the discretion of states, which are guided by not only their national sense of law, but also their national interest. The 
other source - treaties - admittedly gains in importance, as relations developing at a hitherto unknown rate demand to be quickly systematised legally, while customary law is of no help. Conventional norms, however, often established under the supremacy or even pressure of a group of states, sometimes of a single power, too often bear the mark of a moment or political circumstances; they jar the sense of law of some societies, infringe the interests of others and are far from the authority that legal norms ought to enjoy. When, however, as it often happens, each party, approving some compromise wording of a provision, readied an interpretation of its own in advance, then it transpires as soon as the agreement comes into force that each party had signed something else: instead of one there are actually several treaties.

Where can an authority be found that could impose uniformity here? We should not deplore the absence of such, because it follows from the very nature of international law, which is based on recognition-express or implied — by states, i.e. the subjects of international law. This is the principle that in ancient times in Poland was expressed by the classic formula: "nothing on us without us". Or even more: with the exception of few minor cases (e.g. certain resolutions of the League of Nations of an organisational character) that must be clearly provided for, the states enjoy a clear liberum veto, i.e. they may block resolutions on matters in which they are involved. This state of affairs may cause some inconvenience and attempts are made to limit this liberum veto at least where this is possible: in international organisations. For instance, the charter of the International Communications and Transit Organization at the League of Nations stipulates that a 2/3 majority of votes of states represented at a general conference is necessary for the adoption of any draft resolution. Hence, a single state may not block the adoption of the text of a convention, but the convention, of course, will bind only the states that ratify it. It may even happen that the text of a convention will be adopted but the convention will not be validated or will not come into force due to the insufficient number of ratifications. 
The principle of "nothing on us without us" is only a natural consequence of state sovereignty and the surest palladium of national liberty, but does not-for that matter-make the formulation of international law any easier. As a result, it must be said that international law has relatively few universally binding norms; many more norms belong to particular international law. The latter are recognised by only some groups of countries. The renowned Italian scholar Anzilotti was right when he wrote that "the largest part of international law is made up of particular law".

Finally, the codification of international law has no powerful stimulus comparable to an aspiration for political unity; quite on the contrary, every state adamantly defends its independence that-alongside differences in the sense of law and different interests — sets limits on the efforts at legal unification in the area of international relations, which are quite frequent nowadays. Hence, these international movements and organisations that have as their objectives the foundation of some kind of an European or world federation, a universal "super-state", see the codification of international law as one of the roads towards this objective. Nevertheless, it is quite obvious that the introduction of such a political factor to the question of codification should make governments extremely cautious and demands the utmost prudence.

Over one hundred years ago, two outstanding German scholars clashed over the question of civil law codification. As a matter of fact, both the scholars were of French descent and the echoes of this clash have reverberated ever since. In 1814—right after the victory over Napoleon, when national enthusiasm was at its peak-Thibaut published the pamphlet On the Necessity of a General Civil Law for Germany. A barbarian patchwork of Germanic laws, Church law and Roman law was no longer fitting for a victorious nation; a single model act was necessary, one independent of the will of the governments of particular German states, and unifying all Germans in a sense of brotherhood. It is not only a patriotic tendency that is discernible in this approach, but also a large dose of rationality and an exaggerated cult of the Statute famil- 
iar to us from the French Revolution. A similarly patriotic response to Thibaut's views was provided by Friedrich Carl von Savigny. The latter, if not the most profound then the most celebrated representative of the young historical school in jurisprudence, published his views in the pamphlet Vom Beruf unserer Zeit für Gesetzgebungund Rechtswissenschaft (1814). The national genius creates law in the same way as it produces language, custom, poetry and entire folk art. It is customary law that is always alive, perfectly suits society's sense of law and therefore is the best. Admittedly, there must come a time when people's direct legal creativity is no longer possible, and this is when learned jurists come into play. However, the role of the legal profession is rather what we would call today legal technique. The sources of law still spring from the depths of national genius. A statute does not create law, but rather formulates law that is alive in society's sense of law or even in its awareness of law. A code should be a perfect expression of this law, hence it ought to be preceded by a thorough study of the nation's past, character, work and needs, as well as the careful cultivation of jurisprudence; even language must be prepared for this task. Every statute carries a risk of interrupting the development of living law, of petrifying it. A codification that would not suit completely the nation's sense of law or would be simply premature could do irreparable harm to society.

It is easy to notice the affinities between this view and the general trend of romanticism, which is well illustrated by a portrait of Savigny, drawn by Miss Claude (as early as in 1826) in a very romantic manner. A beautiful face lost in thought, eyes looking into the distance, hair falling down in soft curls, a cloak casually draped around shoulders - all this speaks volumes about the times... This view prevailed: uniform civil law for Germany came to pass almost one hundred years later. Since then, however, supporters and opponents of codification have been returning to the ideas set out in essays by Thibaut and Savigny.

How did people envision the question of international law codification? We ignore a draft of the "Declaration of the Law of Nations" 
(or rather states) submitted to the Convent by deputy Fr. Grégoire (1795); it began with a statement that "peoples (or rather states) remain with respect to one another in a natural state joined by the ties of universal morality" followed by 21 articles formulating not so much the international law norms in force as the postulates of revolutionary philosophy. It never went beyond the drafting stage.

The necessity of codifying the law of nations was mentioned first, I think, by Jeremy Bentham, who saw it as a road to permanent peace. In his ideas, however, the great Utilitarian turned out to be a utopian. The formulas included in von Traitteur-Luzberg's Skizze zu einem Völkergesetzbuche (1814), which seem to be of little value, were dissected in a book by Zenon Przesmycki, to which I shall return. The first draft of a code of international law, comprising 414 articles, was published by a Spaniard, de Ferrater, in 1846; an Italian, Paroldo, followed in his footsteps in 1851. The declarations made by Garden (1852) were never fulfilled, while works by Weiss (1854 \& 1858) are codes of neutrality law and maritime law in name only. Only in 1861 did the Austrian jurist von Domin-Petrushevecz publish Précis d'un code de droit international, a critical and thorough compilation-though not free from mistakes — of formulas in which he captured positive international law, both public and private.

The Instructions for the government of armies of the United States in the field drafted by Francis Lieber in 1863, were different in nature, codifying the rules of land warfare in 157 sections. The Instructions was commissioned by the US government for the use by the Union Army in the Civil War. The work by the outstanding scholar paved the way that led to - via Brussels and Oxford attempts - to The Hague Rules of Land Warfare of 1897. Lieber was followed by Bluntschli, who in 1868 published a work entitled Das moderne Völkerrecht der civilisirten Staaten als Rechtsbuch dargestellt. Over-praised and translated into over a dozen languages, this work, later subjected to critical dissection, turned out to be weaker than expected. Next to its undeniable advantages, among which 
the great erudition and broad horizons of its author must be mentioned first, we find in it not only serious drafting mistakes but also major shortcomings in the system, internal contradictions and, finally, a confusion of the author's personal views with the objectively existing norms pertaining to international law. Nevertheless, Bluntschli's work, made a great contribution to the popularisation of the law of nations, unmatched by the works attempting to advance codification written by his successors. Their number is quite considerable. Dudley Field (1872), Fiore (1890), Duplessix (1906), Internoscia (1910), the former president of Brazil, Epitacio Pessoa (1911), not counting the authors of incomplete or partial attempts, such as Farnese (1873) and others. Their codification attempts had one trait in common-perhaps with the exception of that by von Domin-Petrushevecz - their aspiration was not to codify precisely existing positive international law, but rather to supplement it; to create new law in agreement with their views and preferences. Hence, they could be called philanthropists in the meaning given to this word in the 18th century: friends of humanity (amis de l'Humanite).

A Polish jurist will find with justified contentment that, among the few works on the subject, an extensive dissertation written by Polethough in Russian — came out as early as in 1886, which addressed the history and provided a critical analysis of codification attempts in international law. The Polish character of the work can be detected in the first place in the way its author discusses issues, and in the direction he searches for answers to questions posed; the reader senses, knows, that the author is thinking all the time of the Polish question in international law. The juvenile author, Zenon Przesmycki, was awarded the Warszawa University Gold Medal for this dissertation. Certainly, few know today that Miriam (Przesmycki's pen name) began his writing career with a juristic dissertation, having studied international law. Only later did he become a prince of Polish poets and make unforgettable contributions to Polish culture. He covered the same road as the great Grotius but in the opposite direction, for the latter began his amazing writing career that 
earned him the name of the Father of international law with a volume of poetry.

More fruitful than individual efforts, the work of the Institute of International Law has continued now for almost six decades.

As early as 1855, Prof. Kaufmann from Bonn published a work entitled Die Idee und der praktische Nutzen einer Weltakademie des Völkerrechts. Ten years later, this idea was taken up by the well-known Belgian jurist Rolin-Jaequemyns, but only in 1871 did Francis Lieber, already mentioned earlier, write him a letter in which he recognised the advantages of regular congresses of international law scholars; congresses that would be independent of governments and purely academic. Their purpose would be to prepare the partial and gradual codification of the law of nations. Now, backed by Lieber's authority, encouraged by the Swiss Moynier, Rolin-Jaequemyns was in the position to approach over a dozen of the most eminent international-law scholars with specific proposals. In September 1873, in one of the halls of the historical Ghent City Hall, in the presence of almost twenty participants, the Institute of International Law was founded and immediately set out to study systematically selected questions of our discipline. The founding of the Institute was welcomed by international law scholars as a historical event of great importance. The founder of the Italian School in international law studies, Stanislao Mancini, greeted the founding of the Institute in a lecture with a title similar to one von Savigny delivered many years earlier: Vocazione del nostro secolo per la codificazione e la riforma del diritto delle genti.

Realising that the study of international law required a lot of time and that any ideas regarding codification called for extreme caution, the Institute has always exercised praiseworthy prudence in embarking on the study of selected questions of the law of nations. In the several dozen volumes of its yearbooks, there are invaluable materials for the codification of international law, both public and private.

Besides this Institute, the American Institute of International Law has been active for over ten years. I shall return to it in a moment. 
Founded in 1919, Union juridique internationale was not viable. The unification of maritime law, though for the most part private, was greatly helped by the Maritime Committee in Antwerp. Interest in the issues of international law and its codification is stimulated widely by the International Law Association, which was founded in 1873 as the Association for the Reform and Codification of International Law and remains under British influence. Similar but less effective efforts are undertaken by the Inter-Parliamentary Union (since 1889), League of Nations Union and finally diverse pacifist organisations.

Finally, it must be observed that research into international law that has been flourishing for several decades now also paves the way for steps towards its codification.

How do official attempts undertaken so far look? Since almost the first day of its existence, the Institute of International Law has focused its studies on the questions of peaceful settlement of international disputes, and extradition. A convention on the former question was not signed until the Peace Conference in The Hague in 1899, before it was expanded and supplemented at a second conference in 1907. The convention is largely a record of the customary law that had developed in this field, but it does list certain innovations as well (special mediation or international commissions of inquiry). After the war, the Permanent Court of Arbitration was set up at The Hague and conciliatory proceedings have been widely adopted. However, various countries are parties to various conventions; even The Hague arbitration procedure is only auxiliary in nature. Is it possible to speak in this respect of codification at all? As regards extradition, which has been regulated by countries from time immemorial through numerous - and as a rule-boilerplate bilateral agreements, it has been recently assessed as ... not ripe for codification by a League of Nations commission.

In 1880, the Institute, encouraged by the success of Lieber's Instructions and not discouraged by the failure of the Brussels Conference in 1874, embarked on the codification of the laws of land warfare that 
only came to be written down in the form of a convention in 1899 (the so-called Hague Rules) and subsequently revised in 1907. Curiously enough, there are countries that have not adopted the Rules; there are certainly others that have acceded to the 1899 Convention but not to the revised Convention of 1907, while the Convention is applicable only if all belligerent states are parties to it, or else customary law comes into play. The "codification" of the laws of sea warfare (the London Declaration of 1909) has never ripened into an agreement.

The rules of navigation on rivers dividing or crossing two or more countries laid down in Articles 108-116 of the Final Act of the Vienna Congress have been the subject of many later agreements that by no means always followed the 1815 Treaty. The Final Act was followed by others in 1856 (Danube) and 1885 (Congo and Niger); the Institute took on this question in 1883. The Versailles Treaty brought further provisions in this respect and only in 1921, at the Barcelona Conference, was the Barcelona Convention and Statute on the Regime of Navigable Waterways of International Concern adopted, which was meant above all to be the codification of norms applicable to these questions. The Convention has introduced many worrying innovations such as provisions on river works and river administration; it has not been ratified by many countries of prime significance for international navigation. Finally, yet importantly, the Convention, similarly to others, has not supplanted customary law, thus it is not an instance of codification in the proper meaning of this word.

Similarly, one can speak of Hague conventions on private international law as codifications, but only with some reservation. The same is true for Brussels conventions on maritime law.

America seems to be moving at a faster pace along this path, however.

Since 1826, when the first congress of a number of American republics, which had been convened in Panama on the initiative of the great Bolivar, resolved in favour of the codification of the international law they had adopted, the idea of codification has enjoyed sustained popularity. The codification of private international law was the purpose 
of congresses in Lima (1877) and Montevideo (1888). A major preparatory step in this direction was taken by Pan-American conferences (1st, Washington 1889, 2nd, Mexico 1901, 3rd, Rio de Janeiro 1906, 4th, Buenos Aires 1910, 5th, Santiago 1923, 6th, Havana 1928). Implementing the resolutions of the 3rd Conference, a congress of American jurists gathered in Rio de Janeiro in 1912. It is to this congress that we owe the draft codes of public (Pessoa) and private (Pereira) international law. The 5th Conference approached the task from a different angle: having given up on complete codification, it resolved to strive for a partial and gradual one. The prime mover behind these efforts is the renowned Chilean jurist Alejandro Alvarez, residing mainly in Paris. The American Institute of International Law adopted 30 draft conventions that covered almost all public international law (Lima 1924) and discussed a draft code of private international law, drawn up by the excellent Cuban jurist de Bustamante (Montevideo, 1927). The new congress of American jurists (Rio de Janeiro, 1927) approved 12 draft conventions concerning public international law and the draft of an overall convention, covering all private international law. Curiously enough, the word "codification" is not used there; instead, it has been replaced by the "development" of international law. The 6th Pan-American Conference adopted seven agreements, concerning public international law and de Bustamante's code of private international law. The American efforts at codification are accompanied by enthusiasm and optimism unknown elsewhere. True, it is all about particularly American law and the republics of the New World are not divided by so many and such deep differences as the countries of Europe are. But again, on the Old Continent, worries are expressed that this American impetus, ignoring the state of other parts of the world, will hamper, if not prevent, the work on bringing international law to universal unity...

Supposedly, this last task is to be given to the League of Nations, which is repeatedly accused of delaying tactics by the enthusiasts of quick and complete codification of the law of nations. 
When, in the summer of 1920, the committee of ten jurists was drafting the Statute of the Permanent Court of International Justice, it had to allow for the imperfect state our branch of law was in. For this reason, it adopted a resolution on 21 July in which it argued that security called for extending the rule of the law of nations to new domains and advancing further the international judiciary, which was hampered in its development by the imperfections of the law. Hence, the committee proposed that, following the pattern set by the first two Hague conferences, periodic conferences be held in The Hague pour l'avancement du droit international. The proposition was not acceded to by the 1st Assembly of the League. However, already in 1924, the Swedish delegate to the 5th Assembly proposed a motion to draft conventions in matters in which states, recognising fundamental legal norms, differ in their interpretation and application, and, if possible, in matters that had not been regulated at all by the law of nations until then. Since then, the matter of international law codification was on the agenda of the League. A committee of experts was appointed that in four annual sessions (1925-1928) and during intervals between the sessions prepared materials for the future conference. The committee, following the example set by other consultative bodies of the League, addressed governments twice: for the first time to learn about their views on the questions and methods of codification in general and find out what their stance was on a number of issues with regard to which codification appeared desirable and feasible. For the second time, the committee addressed governments after it had selected three issues to be discussed at a future conference. By sending out questionnaires, it intended to collect information on the views the states had on the legal status of these issues, the state of international practice and, finally, ideas and postulates of the states regarding these issues. ${ }^{2}$

2 The work and methods of the commission of experts are discussed at length in the article by S. Rundstein, member of the commission on behalf of the Polish Government. S. Rundstein, Kodyfikacja prawa międzynarodowego, "Ruch Prawniczy, Ekonomiczny i Socjologiczny” 1928, vol. 1. 
The selected issues cover citizenship, territorial waters and the responsibility of a state for damage done to foreigners and their property on its territory. The materials collected for the use of a conference (mainly government replies to the questionnaires) make up three bulky volumes.

The 9th Assembly of the League (1928), being very cautious in making plans for the immediate future, adopted a resolution nonetheless in which it expressed the wish that the Council would appoint a committee of three jurists to draw up a list of all international law issues suitable for codification without predetermining the order in which they were to be worked on. The Assembly also expressed that these same jurists would explore the possibility of publishing existing general conventions (i.e. open for all states) in the form of a code or rather a corpus juris systematically organised and kept à jour. This was done and the 10th Assembly of the League (1929); having taken cognizance of the list of issues suitable for codification, it expressed the wish that the commission of experts should continue their work after a future conference. Furthermore, the Assembly, approving the opinion of the three jurists that a systematic publication of general conventions in the form of a corpus juris would not be possible now, found it to be beneficial to determine the texts of agreements concluded by various states on certain matters and specify which states were bound by these agreements. Thus, the League did not swerve from the course it had taken and along which it intends to proceed slowly and cautiously as before.

4. The second Hague Conference ended its proceedings with a resolution that after a certain time, similar to the period that had lapsed between the first and the second Conference (1899-1907), the third Conference would be convened, preceded by long and thorough preparations, involving matters suitable for international regulation in the near future (susceptibles d'un prochain règlement international). The term "codification" was not used there and probably rightly so, because it would have to mean something else with respect to international law and domestic law. Indeed, this is about very different things. First, the 
issue concerns writing down in the form of an agreement the customary law in force, which in domestic relations has always been treated as only one of preparatory works for codification. Next, the aim might be to supplant many bilateral agreements on a certain subject with a single general multilateral agreement. This is sometimes necessary for practical reasons and technically possible if general rules embodied in analogous provisions can be derived from a multitude of bilateral agreements: the Universal Postal Convention or the Berne Convention concerning the Carriage of Goods by Rail attest that such a manner of proceeding serves the purpose. But then again, the example of the Barcelona Convention or the abandoning of the general extradition convention shows that a general convention does not always mean progress. Finally, the purpose is often not to compile the existing rules in force in an agreement, but rather to introduce new things, often contravening the law in force, that is to say, to "reform" international law. The mere compilation of customary law norms in an agreement could not be achieved without negotiating them, that is, without making some changes: deleting some norms and introducing others. As long as this concerns subordinate norms of, let say, an organisational, technical or executive nature, the matter may not raise any doubts; but what about more fundamental norms that touch the foundations of international law?

In this connection, supporters of "codification" indicate the advantages of establishing what the law is. The certainty of legal norms is indeed a serious argument for written law; the necessity of removing ambiguities, differences or contradictions follows naturally from the legal ordering imposed by an agreement. However, these advantages are not absolute. Experience shows that states often refuse to accede to a convention, disapproving of the approach it takes and the technical implementation of the principles that they by no means question. Pillet, the the old Paris Professor, had earlier noted the danger threatening the entire convention when one of its clauses is breached. In customary law, there is no such relationship. Finally, one should not disregard the 
consideration that although the principle pacta sunt servanda is a foundation of international law, customary law as a rule enjoys greater esteem than conventional one.

Admittedly, conventional law is easier to learn about, and it is more accessible for the general public than customary law. Besides, conventional law makes the task of international courts of arbitration easier. However, it must not be forgotten that law having an agreement as its source may be abolished by conflicting customary law.

One can hardly agree with the excellent Belgian jurist de Visscher, who claims that written law gives smaller and weaker states greater guarantees than customary law. After all, international law is an outcome of clashes between different senses of law of various nations, their different ethical views and conflicting interests. However the forces at play here are distributed, as it were, in time and space; ultimately, those norms remain that best suit the needs of all members of the international community. Those who have taken part in concluding great international agreements know what a great role the pressure of great powers plays on such occasions, the more so as it is concentrated in time and space. They ruthlessly pursue their political and economic goals. On other occasions, pressure comes from the public opinion stirred by agitation; let's say, from the organised and more active segment of the general public, for instance pacifist societies. Do I have to remind you of the revolutionary appeal made by Lord Robert Cecil from the rostrum of the League of Nations to "working-class and peasant masses" concerning disarmament? Furthermore, pressure is exerted by League agendas, including its Secretariat itself at times; when the text of a convention is adopted by a majority of votes, do I need to remind you of the relentless pressure brought to bear by the League on the states to ratify the convention that does not suit them? Frequently, pressure comes from the highest international financial circles, secret societies, the press doing their bidding, and finally the pursuit of popularity or even electoral considerations at home play a part. Therefore, the value of international agreements as the source of law by 
no means grows in proportion to their constantly growing number and the ease with which they are concluded now, owing to the technical and organisational assistance of the League of Nations. Sometimes, the legal value of today's agreements makes one long for the quality of, let's say, the Hague conventions.

Usually, a distinction is made between lawmaking agreements, being a source of international law (the Germans call them Vereinbarung), and contracts representing ordinary transactions between states (Vertrag). Sometimes, in a brutal play of interests, the distinction is obliterated, which by no means adds moral authority to lawmaking agreements. Under these conditions, it must be considered exceedingly dangerous to try-as the Ministry of Foreign Affairs seems to approve- to "preclude the imposition of any time limits on agreements and the possibility of their termination ... to make agreement-based norms override agreements ... A norm overriding the fluctuations of the will of the parties is the objective of the League of Nations, wishing it to be a characteristic feature of lawmaking conventions". ${ }^{3}$ There is a fear that the codification of international law may be used for political ends.

Not only states may bring "politics" to "codification". This can be done-and is done quite openly_-by international movements and organisations working towards the fundamental "reform" of the law of nations. They take every opportunity to try to undermine the "fetish of sovereignty"; in closing legal "loopholes" and extending international regulations to domains hitherto not covered by them, they see a means to restrict the domestic jurisdiction of the state. Frequently, they consider this exclusive jurisdiction as the range of activity "conceded" or "delegated" to states by the international community. They push for obliterating borders, eliminating differences between states and imposing universal unification. In opposition to the state as a subject of international law, they put forward the individual and class. They impose an

3 S. Rundstein, Kodyfikacja prawa międzynarodowego, "Ruch Prawniczy, Ekonomiczny i Socjologiczny” 1928, z. 1. 
obligatory judiciary, regardless of the consent of the parties, demand that particular states disarm but also that penal measures and an international executive be introduced. Behind this agenda lies the idea of a "superstate" and single government that would be so powerful that nobody can or dare resist it. This would be the end of international "anarchy" but also the end of independent nations and the end of states, which would be reduced to the markings of territorial divisions. This would be the end of international law as well.

Both the countries that impose their interests and the international movements or organisations that impose their conceptions... and surely interests as well, know what they want, what their objectives are and are capable of realising their plans step by step with admirable determination and enviable persistence. The situation is worse for those countries that do not have a guideline, are incapable of consistency in their actions, or ca not muster up persistence in their aspirations. Great Britain is a paragon in this respect. After all, any action ought to be based on this assumption: know international law and have some policy on international law.

Bringing order to international law may and should be supported in the areas where this is needed and feasible. I do not see any harm in this, if this is called the "partial and gradual codification" of international law. Caution and absence of haste are crucial: after all, it is not only about the sense of law that nations have and that cannot be violated, not only about interests, but many a time about the very existence of a country. Instructions given in this spirit by the US government to its delegation to the 2nd Hague Conference are full of wisdom. It is necessary to choose carefully the matters for codification conventions and give up total codification, following a plan set in advance. Moreover, we should stick to practical, concrete matters without going into fundamental questions. In every detail, however, we should bear in mind the fundamental principles of the law of nations. For this reason a convention on the "fundamental rights and duties of states" would be dangerous, although the "Declaration on Rights and Duties of States" adopted 
by the American Institute of International Law in 1916, is very useful, representing a warning, steeped in the spirit of freedom, against universalist, cosmopolitan and anti-state tendencies.

One of the authors of the Napoleonic Code, Portalis, said: Les codes des peuples se font avec le temps, mais, à proprement parler, on ne les fait pas. The same is true, a fortiori, about international law. When an outstanding legal scholar, Th. Niemeyer, was writing three years ago Vom Beruf unserer Zeit zur Kodifikation des Völkerrechts, he asked himself two questions: Is the matter ripe enough for codification? and, Are our times capable of performing this codification task well? His answers demanded rather... prudence. Another German international law scholar, K. Strupp, remembering the discussions held in the Institute of International Law 50 years ago said in 1929, not without melancholy, that heute wie vor fünfzig Jahren die Methode der Kodifikation noch immer höchst unvollkommen ist.

For a long time Poland did not participate in the shaping of international law, which had once developed with her commendable participation. Now, when she stands again among nations equal to all others, she has not only a right but also a duty to be present and active in all the places where international law is forged in a bitter struggle or a peaceful debate. Not only because she has the right to demand that the developing norms of international law not infringe her interests and not insult her sense of law, but also because in her millennium-old tradition of international relations, in her legal culture and political thought, she has high moral and legal values that she is obliged to contribute to the common treasure trove of the law of nations. This is Poland's duty to herself and the international community.

\section{Literature}

Rundstein S., Kodyfikacja prawa międzynarodowego, "Ruch Prawniczy, Ekonomiczny i Socjologiczny” 1928, 1. 
